\title{
The innovative personal potential: the content of the concept and empirical study
}

\author{
Valeriia Kapustina ${ }^{1, *}$, Eugenia Bykova $^{1}$ \\ ${ }^{1}$ Department of psychology and pedagogy, Novosibirsk State Technical University, 630073, Novosibirsk, Russia
}

\begin{abstract}
The article is devoted to the theoretical analysis of an innovative personal potential as a psychological construct. Well-known definitions of an innovative personal potential have such characteristics as openness to new information and experience (cognitive component), a desire to change/willingness to create something new (motivational component), innovative activity (behavioral component) and value-semantic system (axiological component). The empirical study of an innovative personal potential of student was held in Novosibirsk State Technical University. Authors used psychological tests (KTS by D. Keirsey, TAS by S. Badner; Tests by F. Williams, the scale of self-esteem of an innovative personality traits by N.M. Lebedeva, A.N. Tatarko, "Problems of the real world" by R. Sternberg). The sample included 177 students. The correlational analysis showed that students, who consider themselves innovative persons, show interest, plays with ideas, reflects on the hidden meaning. They are tolerant to new situations, to the emergence of possible difficulties, they tend to be open, relaxed, free, mobile, trendwatching and are able to deviate from obvious and generally accepted things and develop a simple idea to make it more interesting. Also, it is found that Rational and Idealist types have more apparent characteristics of an innovative personal potential.
\end{abstract}

\section{Introduction}

The Strategy of socio-economic development of Russian Federation until 2020 (Strategy-2020) suggests the transition to a innovative way of country's changes that was presented in a project "The concept of innovative development 2020". At the same time there is no accepted scientific approach to the definition of "innovative personality" in psychological science, so it requires an additional analysis of the concept of innovative personality, factors and conditions, influenced on the development of the innovative personal potential.

The research of the best practices of work with talented pupils and students, which was held by Russian union of rectors together with High School of Economy, showed that there is no system of network interaction between subjects of work with talented children and youth (teachers of schools, universities, employers' organizations). The trajectories of support of talented young people in school and university do not relate with each other, there is a weak continuity in support of talents from level to level.

It makes actual an aimed impact on the personal innovativeness in the education system of Russia and in the Novosibirsk region. It is a necessary stage in the development of giftedness among modern young people in the region, characterized by a large number of visiting young people from other regions and states (Altai Krai, Krasnoyarsk Krai, Zabaykalsky Krai, Altai Republic,
Republic of Khakassia, Kazakhstan etc.). Continuity in support of gifted young people between secondary and higher education would make possible to use the existing potential of future workers more effectively because of using of individual trajectories of youth development in the process of training in the senior classes and in the university.

\subsection{Innovative personality}

The theoretical analysis let us state a certain difference of the scientific ideas of a content of the concept "personal innovativeness" (considering the contexts of the innovative personal potential, innovative personal culture, innovativeness as a personal component). At the same time there is a common set of such features of the innovative person as a creativity, a communicative competence, a reflexivity, a risk appetite, an activity, striving for success, etc.) in scientific sources.

Despite the obvious interest to the personal innovativeness in a scientific world, we have found that there is no common opinion about components of innovativeness and ways of development of innovative person. The talent management, which is aimed on the development of abilities, including the creative potential of young people and improving the competitiveness of graduates in the labor market, is actively developing abroad [1-3], but Russian specialists mostly try to influence individual traits of students in order to increase their innovative potential $[4,5]$.

\footnotetext{
* Corresponding author: pskabinet@gmail.com
} 
The analysis of theoretical views about innovative personality, which was made by V.A. Artemeva, let us describe innovative personality as "a person with innovative thinking (ability to percept, create, fine-tune and implement new and original ideas, included in the innovative process" [6]. This approach to understanding of innovativeness is close to the position of study of an innovative personality of A.V. Karpov and S.V. Kurochkina. These authors argue that participating in innovative activity is determined by such factors in personal structure as communication (social skills), intellect, creative potential, which is necessary for productive activity. In the structure of personal traits of students-participants of innovative process, the basic role is played by sensitivity, warmth, intellect, dominance [7]

V.A. Artemeva studies innovative style, which includes creativity, dedication, orientation on success, social responsibility $[6,8]$. Author defines the innovative position of person as "an interrelation of needs, interests, beliefs, understanding about self and world around in terms of potential readiness for future changes" $[8, \mathrm{p}$. $80]$, but doesn't give a definition of an innovative style.

We suppose that an innovative style as a construct is similar to an understanding of an innovative mindset of D. Stauffer, who describes this concept as a not necessarily conscious assumption or belief that impacts behavior, making decisions and forming of preferences [9].

At this moment theoretical and empirical data about innovative personality looks like patchwork quilt and requires further clarification. As it seems to authors, one of the ways to specify the psychological investigations devoted to the innovativeness is to differ basic constructs (innovativeness, innovative personal potential, innovative features). In this article we prefer to focus on an innovative personal potential as the most integrative characteristic.

\subsection{Innovative personal potential: the structure}

Innovative personal potential is understood by V.E. Klochko and O.M. Krasnoryadtseva as an integral system characteristic, which determines an ability to generate new forms of behaviour and activity by using the same possibilities that are opened to him in a complicated dynamics of of value-semantic dimensions of his living area and to provide a self-development as a strategic life-sustaining factor [10].

R.B. Tucker also told about an importance of innovative behaviour, which includes the using of an innovation in different ways of doing work, taking innovative actions in any job and activity, adding value to an actual statement, so it makes innovative behaviour a result of innovative thinking [11].

The structure of an innovative personal potential by Yu.A. Vlasenko includes 3 components [12]:

- the gnoseological aspect (the possibility of finding a new informational space and orientation in it);

- axiological aspect (the possibility of an adequate assessment of the new phenomenon);
- the praxeological aspect (the ability to act effectively in a new situation).

N.M. Lebedeva studied Canadian, Russian and Chinese samples and found that value of an openness to changes (autonomy, stimulation) and universalism contribute to positive innovative attitudes, but traditional values impede innovativeness [13]

S.A. Bogomaz and D.Yu. Balanev suggest including a hardiness to the structure of an innovative potential. According to their data students, who involved in innovative activity, have more pronounced resilience, motivation to realization, leadership, importance of themselves, they are open to world around and can percept new situation in life as a challenge [14].

T.D. Kim describes innovative professional potential as a characteristic of individual psychological features, based on an ability to execute an activity, aimed on development, implementation and dissemination of new ideas, products and technologies, successfully. Innovative potential due to T.D. Kim consists of 6 elements: life activity, desire to change, social independence, business responsibility, original (extraordinary) thinking, innovative competence [15].

E. Gasenko, describing the innovative potential of personnel, suggests 5 groups of criteria of innovative potential: intellectual willingness to innovation, motivation, communicative skills, innovative activity, personal features (flexible thinking, initiative, willingness to use new abilities) [16].

The structure of E. Gasenko is similar to the vision of common components of creativity and innovation of $\mathrm{M}$. Kumar and A. Bharadwaj: expertise, creative thinking, intrinsic task motivation, group task characteristics, diversity and knowledge in team members, external demands [17]. But these authors also mentioned the position of M. Patterson et al., who considered novelty as a factor, which differentiate creativity and innovation: innovation includes the use of new and original ideas, but it leads to something new and socially useful [18]. It makes possible to conclude that the main difference between creativity and innovation due to M. Patterson et al. is an innovative behavior.

All these definitions have in common such characteristics as openness to new information and experience (cognitive component), a desire to change/willingness to create something new (motivational component), innovative activity (behavioral component) and value-semantic system (axiological component).

These components formed the basis of the empirical part of the study of an innovative personal potential.

\section{Materials and methods}

The empirical study of an innovative personal potential of student was held by authors in Novosibirsk State Technical University.

The object of study is an innovative personal potential.

The purpose of study is to find out specific of characteristics of an innovative personal potential of 
students with different temperamental type (due to Keirsey).

\subsection{Methods}

Methods of the research are:

- Theoretical analysis of scientific literature;

- Psychological tests (The Keirsey Temperament Sorter (KTS), The Tolerance Ambiguity Scale (TAS) by S. Badner; Test of creative personality and Test of Divergent Thinking by F. Williams, The scale of selfesteem of an innovative personality traits by N.M. Lebedeva, A.N. Tatarko, "Problems of the real world" by R. Sternberg).

The battery of tests is presented in table 1 .

The sample included 177 students of Novosibirsk State Technical University (Novosibirsk, Russia).

Table 1. Battery of psychological tests

\begin{tabular}{|c|c|c|}
\hline $\begin{array}{c}\text { Component of } \\
\text { innovative personal } \\
\text { potential }\end{array}$ & Scales of test & Name of test \\
\hline $\begin{array}{l}\text { cognitive } \\
\text { component }\end{array}$ & $\begin{array}{l}\text { Originality, } \\
\text { curiousity }\end{array}$ & $\begin{array}{c}\text { Test of creative } \\
\text { personality and } \\
\text { Test of Divergent } \\
\text { Thinking by F. } \\
\text { Williams }\end{array}$ \\
\hline $\begin{array}{c}\text { motivational } \\
\text { component }\end{array}$ & $\begin{array}{l}\text { tolerance for } \\
\text { risk, tolerance } \\
\text { for an } \\
\text { ambiguity }\end{array}$ & $\begin{array}{c}\text { The Tolerance } \\
\text { Ambiguity Scale } \\
\text { (TAS) by S. } \\
\text { Badner; Test of } \\
\text { Divergent } \\
\text { Thinking by F. } \\
\text { Williams }\end{array}$ \\
\hline $\begin{array}{l}\text { behavioral } \\
\text { component }\end{array}$ & $\begin{array}{l}\text { Self-esteem of } \\
\text { an } \\
\text { innovativenes } \\
\text { s, changing an } \\
\text { environment }\end{array}$ & $\begin{array}{c}\text { The scale of a } \\
\text { self-esteem of } \\
\text { innovative } \\
\text { personality traits } \\
\text { by N.M. } \\
\text { Lebedeva, A.N. } \\
\text { Tatarko, } \\
\text { "Problems of the } \\
\text { real world" by R. } \\
\text { Sternberg. }\end{array}$ \\
\hline $\begin{array}{l}\text { axiological } \\
\text { component }\end{array}$ & $\begin{array}{c}\text { Rational (NT), } \\
\text { Idealist (NF) }\end{array}$ & $\begin{array}{l}\text { The Keirsey } \\
\text { Temperament } \\
\text { Sorter (KTS) }\end{array}$ \\
\hline
\end{tabular}

\subsection{Hypotheses}

1. The innovative personal potential of student includes such characteristics like creativity, tolerance for ambiguity, changing an environment and orientation on future.

2. The structure of intercorrelation of components of an innovative personal potential is different for different temperamental types by D. Keirsey.

\section{Results}

The correlational analysis shows that the "innovativeness" scale (the scale of a self-esteem of innovative personality traits by N.M. Lebedeva, A.N. Tatarko) is correlated to the indicators of all psychodiagnostic tests used in the study.

A positive correlation with the indicator of "curiosity" (Rs=0.16, p<0.02) suggests that students, who consider themselves innovative persons, show interest, plays with ideas, reflects on the hidden meaning.

A positive correlation with "novelty" $(\mathrm{Rs}=0.17$, $\mathrm{p}<0.02)$ and "complexity" $(\mathrm{Rs}=0.16, \mathrm{p}<0.02) \quad$ (The Tolerance Ambiguity Scale (TAS) by S. Badner) means that students, who consider themselves innovative persons, are tolerant to new situations, to the emergence of possible difficulties and difficulties in various situations;

Positive correlations with typological characteristics "extraversion" ( $R s=0.28, \mathrm{p}<0.001)$, "irrationality" (Rs $=0.28, \mathrm{p}<0.001)$, "intuition" $(\mathrm{Rs}=0.34, \mathrm{p}<0.001)$ (The Keirsey Temperament Sorter (KTS)) show that students, who consider themselves innovative persons, tend to be open, relaxed, free, mobile and trendwatching.

Positive correlations with creative characteristics "originality" $\quad(\mathrm{Rs}=0.17, \quad \mathrm{p}<0.01), \quad$ "development" $(\mathrm{Rs}=0.16, \mathrm{p}<0.03)$ and "name" $(\mathrm{Rs}=0.25, \mathrm{p}<0.001)$ (Test of creative personality and Test of Divergent Thinking by $\mathrm{F}$. Williams) indicate that students, who consider themselves innovative persons, are able to deviate from obvious and generally accepted things and develop a simple idea to make it more interesting.

Thus, for successful implementation of innovation activity, a person must possess creative abilities, generate and produce new ideas, design and model them in practical forms of activity; it is necessary to be open to new things, which is based on tolerance to the emergence of difficulties and difficulties in the implementation of new ideas.

We have found significant differences according to the degree of organization of structures in selected groups. The number of correlations in groups of students with temperament types Rational (NT) and Idealist (NF) exceeds the number of connections in groups of students with temperament types Artisan (SP) and Guardian (SJ). Therefore, the consistency of elements in the structure of innovative personal potential of temperamental types of Rational and Idealist is high.

Table 2. Correlations of "The scale of self-esteem of innovative personality traits" and indicators of other psychological tests in the different types of Keirsey temperament

\begin{tabular}{|c|c|c|}
\hline $\begin{array}{c}\text { Type of } \\
\text { temperament } \\
\text { (Keirsey), } \\
\text { sample }\end{array}$ & Correlations & p-level \\
\hline & $\begin{array}{c}\text { Innovativeness\&Extraversion } \\
\text { (Rs=0.64) }\end{array}$ & \\
Innovativeness\&Novelty & (Rs=0.66) \\
Rational & $\begin{array}{c}\text { Risk for a success\&Novelty } \\
\text { (Rs=0.76) }\end{array}$ & $<0.05$ \\
& $\begin{array}{c}\text { Creativity\&Elaboration } \\
\text { (Rs=0.86) }\end{array}$ & \\
& Creativity\&Originality & \\
\hline
\end{tabular}




\begin{tabular}{|c|c|c|}
\hline & $\begin{array}{l}\quad(\mathrm{Rs}=0.80) \\
\text { Creativity\&Fluency }(\mathrm{Rs}=0.80) \\
\text { Creativity\&Intuition }(\mathrm{Rs}=0.72)\end{array}$ & \\
\hline $\begin{array}{c}\text { Idealist (NF) } \\
\quad(\mathrm{N}=10)\end{array}$ & 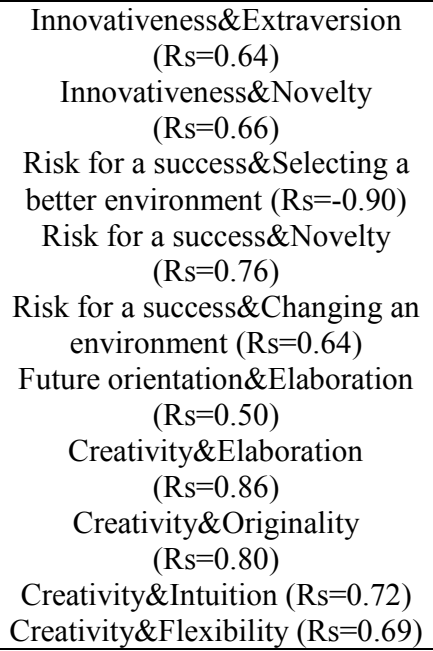 & $<0.05$ \\
\hline $\begin{array}{c}\text { Guardian } \\
\text { (SJ) }(\mathrm{N}=87)\end{array}$ & $\begin{array}{l}\text { Innovativeness\&Extraversion } \\
(\mathrm{Rs}=0.28) \\
\text { Risk for a success \&Extraversion } \\
(\mathrm{Rs}=0.34)\end{array}$ & $<0.01$ \\
\hline $\begin{array}{l}\text { Artisan (SP) } \\
(\mathrm{N}=14)\end{array}$ & $\begin{array}{c}\text { Innovativeness\&Risk }(\mathrm{Rs}=0.57) \\
\text { Risk for a success\&Curiosity } \\
(\mathrm{Rs}=0.67) \\
\text { Risk for a success\&Adaptation } \\
(\mathrm{Rs}=-0.64) \\
\text { Risk for a success\&Extraversion } \\
(\mathrm{Rs}=0.55)\end{array}$ & $<0.04$ \\
\hline
\end{tabular}

\section{Discussion}

The results of an investigation of correlations between a self-esteem of an innovativeness and other components of an innovative potential shows the difference of its structure in different types of Keirsey temperament.

In table 2 we can see, that Guardian (SJ) has correlation of innovativeness and risk for a future only with extraversion, so due to poor diversity of intercorrelations we can assume, that this type of temperament is not inclined to innovativeness, perhaps because this type of personality avoids everything that seems to be unclear. The Guardian (SJ) use to think of the business, seeking to bring an order, an organization and a completion to it. They tend to have serious and responsible attitude to various types of activities and communication, which are recognized by them as the performance of certain and rationally grounded duties.

Artisan (SP) strives for freedom. These are artistic natures, who use to follow their impulses and willingness to risk. They live in the present. These characteristics can explain the resulting correlations of the "risk for a success" scale with "extraversion", "curiosity" in table 2. A negative correlation with "adaptation" indicates that it is not typical to adapt to the situation for a person with this type of temperament, because he's always in a motion. The "innovativeness" of is associated with a "risk". The lack of correlations with the "future orientation" scale can be explained by the fact that the Artisan (SP) type lives "here and now", they prefer to act now rather than expect the future, they like to bring into life the game and unpredictable elements.

For the type of temperament Rational (NT) the "creativity" scale has a large number of correlations with "intuition", "fluency", "originality" and "elaboration". It shows, that the Rational (NT) type is creative, it can not only offer ideas, but also develop them. "Risk for a success" is positively correlated with "novelty", which can be explained by the ability to change and the ability to look at things from different points of view. Thus, the innovativeness of the Rational (NT) type is the desire to obtain new knowledge, openness, the opportunity to consider all possible options.

We can see a lot of intercorrelations of "innovativeness" scale in type of Idealist (NF). The correlations of "creativeness" scale with "flexibility", "originality" and "elaboration" scales indicates, that Idealist (NF) generates ideas and develops them. The intuition function allows them to gaze into the future, so we suppose, that it can explain the positive correlation between "creativity" and "intuition". The "risk for a success" scale is negatively related to the type of interaction with the "selecting a better environment" and positively with the "Changing an environment". This result indicates that the Idealist (NF) type actively interacts with the environment and leaves it when he must struggle. The "Future orientation" scale is positively associated with "Elaboration": it means that the Idealist (NF) type is developing an idea that will work in the future because of an orientation on trends of the future. Thus, the Idealist (NF) type can be named as a creative and open-minded type, who is in a constant search.

So, the correlational analysis let us conclude that innovative personal potential is different for different types of Keirsey temperament.

\section{Conclusion}

The theoretical analysis showed that there is no common opinion about components of innovativeness and ways of development of innovative person. We suppose that the research of an innovative personal potential is a way to specify the psychological investigations devoted to the innovativeness.

We suggest describing an innovative personal potential as the integrative characteristic, which includes an openness to new information and experience (cognitive component), a desire to change/willingness to create something new (motivational component), innovative activity (behavioral component) and valuesemantic system (axiological component).

The correlational analysis showed that the "innovativeness" scale is correlated to the indicators of all psychodiagnostic tests used in the study.

It means that students, who consider themselves innovative persons, show interest, plays with ideas, reflects on the hidden meaning, these students are tolerant to new situations, to the emergence of possible difficulties and difficulties in various situations, they are tend to be open, relaxed, free, mobile, trendwatching and 
able to deviate from obvious and generally accepted things and develop a simple idea to make it more interesting.

Also, the correlational analysis let us conclude that innovative personal potential is different for different types of Keirsey temperament. The number of correlations in groups of students with temperament types Rational (NT) and Idealist (NF) exceeds the number of connections in groups of students with temperament types Artisan (SP) and Guardian (SJ), so we can suppose that Rational (NT) and Idealist (NF) types of Keirsey temperament have more apparent characteristics of an innovative personal potential.

The analytical part of the study was funded by RFBR Project No 19-013-00208.

\section{References}

1. D.G. Collings, K. Mellahi, Hum. Res. Man. Rev., 19 (4), 304 (2009).

2. D.W. Chan, L. Chan, Y. Zhao, (2009), Ed. Res. J., 24 (1), 135 (2009).

3. C. Farao, M. Gianecchini, WOA Organizing between reality and appearance in times of change. (Pisa: University of Pisa, 2017)

4. E.A. Shmeleva The development of the innovation potential of the individual in the scientific and educational environment of a pedagogical university (Nizhegor. State Arch. and Constr. University, 2013).

5. T.B. Zagorulya, Hist. and soc.-ed. thought, 4, 107 (2014).
6. V.A. Artemeva, Bul. Of civil eng., Hum. Sci., 2 (49), 207 (2015)

7. A.V. Karpov, S.V. Kurochkina, Bul. Of YarGU, Human. Sci., 1 (47), 66 (2019)

8. V.A. Artemeva, E.K. Veselova, M.Ya. Dvoretskaya, E.Yu. Korjova, NSPU Bul., 8, 73 (2018)

9. D. Stauffer, Int. J. Of Innov. Sci., 8, 4 (2016)

10. V.E. Klochko, O.M. Krasnoryadtseva, Bul. Of TSU, 339, 151 (2010).

11. R.B. Tucker, Innovation is Everybody's Business: How to Make Yourself Indispensable in Today's Hypercompetitive World (Wiley, 2010)

12. Yu.A. Vlasenko, Sci. Notes, Bio., Math, Psych., etc., 12, 99 (1999).

13. N.M. Lebedeva, Psych. In Ec. And Man., 2, 59 (2010)

14. S.A. Bogomaz and D.Yu. Balanev, Sib. Psych. J., 32, 23 (2009).

15. T.D. Kim, Psychological components of an innovative proffesional potential (YuUrGU, 2013)

16. E.V. Gasenko, Tomsk State University J. of Economics, 2 (18), 44 (2012)

17. M. Kumar, A. Bharadwaj Technological and Institutional Innovations for Marginalized Smallholders in Agricultural Development (SpringerOpen, 2016)

18. M.G. Patterson, M.A. West, V.J. Shackleton, J.F. Dawson, R. Lawthom, S. Maitlis, D.L. Robinson, A.M. Wallace, J. Organ. Behav., 6(4), (2005) 